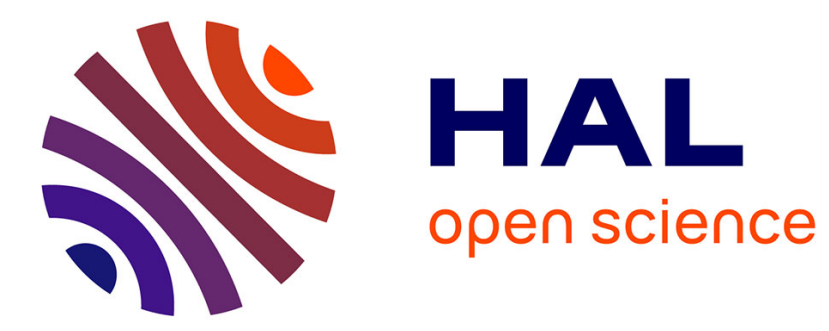

\title{
Transcriptomic and proteomic analysis of [i] Oenococcus oeni[/i] PSU-1 response to ethanol shock
}

Marie-Christine Champomier-Verges, Patricia Anglade, Fabienne F. Baraige, Ricardo Cordero-Otero, Albert Bordons, Monique Zagorec, Cristina Reguant

\section{- To cite this version:}

Marie-Christine Champomier-Verges, Patricia Anglade, Fabienne F. Baraige, Ricardo Cordero-Otero, Albert Bordons, et al.. Transcriptomic and proteomic analysis of [i] Oenococcus oeni[/i] PSU-1 response to ethanol shock. Food Microbiology, 2015, 51, pp.87-95. 10.1016/j.fm.2015.05.005 . hal-01204468

\author{
HAL Id: hal-01204468 \\ https://hal.science/hal-01204468
}

Submitted on 27 May 2020

HAL is a multi-disciplinary open access archive for the deposit and dissemination of scientific research documents, whether they are published or not. The documents may come from teaching and research institutions in France or abroad, or from public or private research centers.
L'archive ouverte pluridisciplinaire HAL, est destinée au dépôt et à la diffusion de documents scientifiques de niveau recherche, publiés ou non, émanant des établissements d'enseignement et de recherche français ou étrangers, des laboratoires publics ou privés. 


\section{Accepted Manuscript}

Transcriptomic and proteomic analysis of Oenococcus oeni PSU-1 response to ethanol shock

Nair Olguín, Marie Champomier-Vergès, Patricia Anglade, Fabienne Baraige, Ricardo Cordero-Otero, Albert Bordons, Monique Zagorec, Cristina Reguant

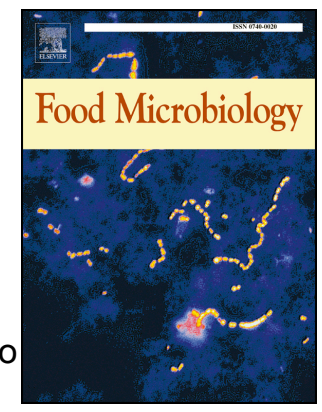

PII:

S0740-0020(15)00099-4

DOI:

10.1016/j.fm.2015.05.005

Reference: $\quad$ YFMIC 2395

To appear in: Food Microbiology

Received Date: 27 January 2014

Revised Date: 1 December 2014

Accepted Date: 11 May 2015

Please cite this article as: Olguín, N., Champomier-Vergès, M., Anglade, P., Baraige, F., Cordero-Otero, R., Bordons, A., Zagorec, M., Reguant, C., Transcriptomic and proteomic analysis of Oenococcus oeni PSU-1 response to ethanol shock, Food Microbiology (2015), doi: 10.1016/j.fm.2015.05.005.

This is a PDF file of an unedited manuscript that has been accepted for publication. As a service to our customers we are providing this early version of the manuscript. The manuscript will undergo copyediting, typesetting, and review of the resulting proof before it is published in its final form. Please note that during the production process errors may be discovered which could affect the content, and all legal disclaimers that apply to the journal pertain. 
1

2

3

4

5

6 Nair Olguín ${ }^{1}$, Marie Champomier-Vergès ${ }^{2}$, Patricia Anglade², Fabienne Baraige $^{2}$, 7 Ricardo Cordero-Otero ${ }^{1}$, Albert Bordons ${ }^{1}$, Monique Zagorec ${ }^{2}$, Cristina Reguant* ${ }^{1}$

8

9

\section{PSU-1 response to ethanol shock}

\section{Transcriptomic and proteomic analysis of Oenococcus oeni}

${ }^{1}$ Departament de Bioquímica i Biotecnologia, Facultat d'Enologia, Universitat Rovira i Virgili, c/ Marcel·lí Domingo 1, 43007, Tarragona, Catalonia, Spain.

${ }^{2}$ Unité MICALIS (UMR1319) équipe FLEC, INRA, Domaine de Vilvert, 78350 Jouyen-Josas, France

\section{*Corresponding author: Cristina Reguant}

Tel: +34 977 558043; Fax: +34 977 558232; E-mail address: cristina.reguant@urv.cat 
26 Abstract

The correct development of malolactic fermentation depends on the capacity of Oenococcus oeni to survive under harsh wine conditions. The presence of ethanol is one of the most stressful factors affecting $O$. oeni performance. In this study, the effect of ethanol addition $(12 \% \mathrm{vol} / \mathrm{vol})$ on $O$. oeni PSU-1 has been evaluated using a transcriptomic and proteomic approach. Transcriptomic analysis revealed that the main functional categories of the genes affected by ethanol were metabolite transport and cell wall and membrane biogenesis. It was also observed that some genes were overexpressed in response to ethanol stress (for example, the heat shock protein Hsp20 and a dipeptidase). Proteomic analysis showed that several proteins are affected by the presence of ethanol. Functions related to protein synthesis and stability are the main target of ethanol damage. In some cases the decrease in protein concentration could be due to the relocation of cytosolic proteins in the membrane, as a protective mechanism. The omic approach used to study the response of $O$. oeni to ethanol highlights the importance of the cell membrane in the global stress response and opens the door to future studies on this issue.

\section{Keywords}

Oenococcus oeni - Malolactic fermentation -Transcriptomic - Microarray analysis Proteomic - Ethanol

\section{Introduction}

Oenococcus oeni is the most important of the lactic acid bacteria involved in malolactic fermentation (MLF) in wine. However, bacterial growth and MLF are not always successful due to the harsh environmental conditions of wine (Davis et al., 1985; 
51 Malherbe et al., 2007). Several studies have been made of how $O$. oeni responds under

52 stress conditions such as $\mathrm{pH}$, temperature, sulfite concentration and ethanol content

53 (Versari et al., 1999). However, ethanol seems to be one of the parameters that most

54 limits $O$. oeni survival in wine. Therefore, if control over MLF in the wine industry is to

55 be improved, it is essential to understand the mechanisms involved in ethanol stress and

56 tolerance in O. oeni.

57 The toxicity of ethanol is generally attributed to its interaction with membranes at the aqueous interface, resulting in perturbed membrane structure and function (Weber and Bont, 1996; Beney and Gervais, 2001). Studies on O. oeni have shown that exposing cells to ethanol increases the permeability of the cytoplasmic membrane and enhances passive proton influx and the concomitant loss of intracellular material (Da Silveira et al., 2003). The permeability of the membrane to protons dissipates the proton motive force and affects ATP synthesis, which is no longer available for growth (Capucho and San Romão, 1994; Salema et al., 1996; Weber and Bont, 1996). This may explain the high mortality when $O$. oeni cells were directly inoculated into a wine-like medium supplemented with 12-16\% ethanol (Da Silveira et al., 2003; Chu-Ky et al., 2005).

Nonetheless, in concentrations up to $12 \%$, ethanol has no significant effect on malolactic activity, but, according to Capucho and San Romão (1994), it does strongly inhibit cell growth. These authors suggest that the mechanisms regulating cell growth are more sensitive to ethanol than the malolactic enzyme itself. On the other hand, we have also found that a number of $O$. oeni citrate pathway genes are over-expressed in the presence of ethanol, suggesting that the citrate metabolism takes part in the response to this stress (Olguín et al., 2009). 
Two-dimensional gel electrophoresis (2-DE) has provided invaluable

76 information on the adaptive response of microorganisms to changes in external

77 conditions (Champomier-Vergès et al., 2002). For instance, Silveira and co-workers

78 (2004) found that ethanol triggers alterations in the protein patterns of $O$. oeni cells that are directly stressed with $12 \%$ ethanol for 1 hour and cells pre-adapted in $8 \%$ ethanol. It has also been shown that cell cultures acclimated with $10 \%$ ethanol survived better in wine, probably due to the differential expression of certain proteins (Cecconi et al., 2009). Functional analysis of gene expression using comparative transcriptomics is also providing insight into stress responses and regulation mechanisms in lactic acid bacteria (LAB). Preliminary microarray analysis of the Lactobacillus plantarum response to several stress conditions revealed unanticipated stress response profiles that correlate specifically with lactate- and pH-induced stress (Siezen et al., 2004; Pieterse et al., 2005). However, no current studies use microarray analysis of $O$. oeni.

The aim of the present study was to evaluate the cell response of $O$. oeni PSU-1 after $12 \%$ ethanol shock using transcriptomic and proteomic approaches. In order to study the effect of ethanol alone on $O$. oeni cells, the assays were performed in rich medium (MRS) at pH 5.0 (De Man et al., 1960) with the addition of ethanol.

\section{Materials and Methods}

\subsection{Growth conditions}

O. oeni PSU-1 was cultured at $30^{\circ} \mathrm{C}$ in a two-liter flask containing MRS broth medium supplemented with L-malic acid $\left(4 \mathrm{~g}^{-1}\right)$ and fructose $\left(5 \mathrm{~g} \mathrm{l}^{-1}\right)$ at $\mathrm{pH}$ 5.0. When cultures reached the late exponential phase $\left(\mathrm{OD}_{600 \mathrm{~nm}} \approx 1\right)$ they were divided and put into two sterile flasks. Immediately, $12 \%(\mathrm{v} / \mathrm{v})$ of ethanol was added to one flask and $12 \%$ (v/v) of water was added to the other (control). The latter was used as a control assay to 
100 evaluate the possible effect of culture dilution on the proteome. At this moment, the

101 quantities of L-malic acid and fructose remaining in the medium were $0.03 \mathrm{~g} \mathrm{l}^{-1}$ and 0.28

$102 \mathrm{~g} \mathrm{l}^{-1}$ respectively. The $\mathrm{pH}$ of the medium was 4.35 . Both flasks were incubated at $28^{\circ} \mathrm{C}$.

103 All assays were performed in triplicate using independent cultures and the growth was

104 monitored by counting colonies on plates of MRS medium (De Man et al., 1960),

105 supplemented as described above. Samples were taken at time zero just before water/ethanol was added, and then at one, three and five hours after addition.

L-malic acid and fructose contents were measured using Boehringer enzymatic kits (Mannheim) on culture supernatants stored at $-20^{\circ} \mathrm{C}$ until use. $\mathrm{pH}$ measurements were taken using a GLP31 pH-meter (Crison Instruments, Barcelona, Spain).

\subsection{Transcriptome analysis}

O. oeni cells were harvested by centrifugation, frozen in liquid nitrogen and kept at $-80^{\circ} \mathrm{C}$ until RNA extraction. Total RNA extractions were performed using the Roche RNeasy kit following the manufacturer's instructions (Mannheim, Germany). RNA concentrations were calculated by measuring absorbance at $260 \mathrm{~nm}$ using a NanoDrop 1000 Spectrophotometer (Thermo Fisher Scientific SL, Alcobendas, Spain). Arrays (090324_Oenococcus oeni expression 4-plex array) were developed by Roche NimbleGen (Madison, WI, USA) and samples were analyzed at the Functional Genomics Core of the Institute for Research in Biomedicine (IRB, Barcelona, Spain). cDNA library preparation and amplification were performed from $25 \mathrm{ng}$ total RNA using WTA2 (Sigma-Aldrich, Madrid, Spain) with 17 cycles of amplification. Labeling, hybridization and washing were performed according to the Roche Nimblegen expression guide v5.1. For each sample, $1 \mu \mathrm{g}$ cDNA was labeled by Cy3 nonamer 
125 cDNA was subsequently prepared. Samples were hybridized to the arrays for 18 hours

126 at $42^{\circ} \mathrm{C}$. After washing, the arrays were scanned in a Roche Nimblegen MS 200

127 scanner. Raw data files (Pair and XYS files) were obtained from images using

128 Nimblescan v2.6 software (Roche Nimblegen). Normalized gene expression values

129 were obtained with Nimblescan software using the robust multichip average (RMA)

130 algorithm as described by Irizarry et al. (2003a; 2003b).

131 Data univariate (ANOVA) analyses of transcriptomic data were conducted using

132 SPSS version 17.0 (SPSS Inc., Chicago, IL, USA). Variable means showing statistical

133 significance were compared using Bonferroni post-test comparisons at a significance

134 level of 0.05 , after testing the homogeneity of variance assumption between the various

135 groups. The results were submitted to GEO (Gene Expression Omnibus Database,

NCBI) under accession number GSE62036.

\subsection{Array validation by real-time $q P C R$}

Several genes were selected by real-time qPCR for validation of the microarray data. The primers used for these analyses are shown in Table 1. Genes OEOE_0289, OEOE_0422 and OEOE_0665 were selected because they have been studied by qPCR before (Beltramo et al. 2006, Olguín et al. 2009, Olguín et al. 2010). Genes

OEOE_1325 and OEOE_1565 were selected due to their involvement in malolactic fermentation. The other genes (OEOE_0258, OEOE_0394, OEOE_0411, OEOE_1325, OEOE_0008, OEOE_0238 and OEOE_1290) were randomly selected with the sole objective of validating the methodology. Real-time qPCR was performed on the same RNA samples used for the microarray analysis. Reverse transcription and real-time qPCR were performed as previously described (Olguín et al., 2010). Primers were designed to be about $18-23$ bases long, to contain over $50 \% \mathrm{G} / \mathrm{C}$ and to have a melting 
150 temperature $(\mathrm{Tm})$ above $60^{\circ} \mathrm{C}$. The length of the PCR products ranged from 92 to 130

151 bp. Clone Manager Professional Suite software was used to select primer sequences and

152 analyze secondary structures and dimer formation. In this work four genes were assayed

153 as internal controls for qPCR - ldhD, dpoIII, gyrA and gyrB - using the primers

154 described by Desroche et al. (2005) and Constantini et al. (2011). Of these, the ldhD

155 gene, coding for lactate dehydrogenase, was the one that showed the least variation

156 under the experimental conditions used (data not shown). For this reason $l d h D$ was used

157 as the internal control. Real-time PCR was performed in $25 \mu$ l final volume containing

$1585 \mu \mathrm{l}$ of diluted cDNA, $1.5 \mu \mathrm{l}$ of each primer at $5 \mu \mathrm{M}, 4.5 \mu \mathrm{l}$ of RNAse free water and

$15912.5 \mu \mathrm{l}$ of SYBR Green Master Mix (Applied Biosystems, Foster City, CA, USA).

160 Amplifications were carried out using a Real Time PCR System 7300 (Applied

161 Biosystems). The threshold value used in this study was automatically determined by

162 the instrument. Results were analyzed using the comparative critical threshold $(\Delta \Delta \mathrm{CT})$

163 method, in which the amount of target RNA was adjusted to a reference (internal target

164 RNA) as previously described (Livak Schmittgen, 2001).

\subsection{Proteome analysis}

Protein extract preparation. Cells cultured in the presence or absence of ethanol were harvested by centrifugation, washed with $10 \mathrm{mM}$ of Tris- $\mathrm{HCl}$ buffer ( $\mathrm{pH} 8.0)$ and frozen at $-80^{\circ} \mathrm{C}$ until analysis. Pellets were then resuspended to a final $\mathrm{OD}_{600 \mathrm{~nm}} \approx 60$ in $0.1 \mathrm{M}$ of

170 Tris- $\mathrm{HCl}$ buffer $(\mathrm{pH}$ 7.5) and cellular extracts obtained using a cell disrupter (BASIC Z;

171 Constant Systems Ltd., Daventry, United Kingdom) at a pressure of 2.5 kbar. The suspension was first centrifuged at 4,500 $\mathrm{x} g$ for $15 \mathrm{~min}$ at $4^{\circ} \mathrm{C}$ to remove unbroken cells and cellular debris. The supernatant was ultra-centrifuged at 50,000 x $g$ for $30 \mathrm{~min}$ at $4^{\circ} \mathrm{C}$ to remove cell envelope components. Protein concentration was estimated using the 
175 Bradford method following the manufacturer's instructions (Coomassie Protein Assay

176 Reagent; Pierce Biotechnology, Rockford, IL, USA).

177 Sample preparation and protein electrophoresis. Protein samples and 2-DE were

178 performed as described by Sánchez et al. (2005), with some modifications. The extract

179 was treated with $1 \mu \mathrm{l}$ of Benzonase (Merck KGaA, Darmstadt, Germany) and $1 \mu \mathrm{l}$ of

$1801 \mathrm{M} \mathrm{MgCl}_{2}$ to remove nucleic acids. The mixture was vortexed and centrifuged at 3,500

$181 \mathrm{x} g$ for $2 \mathrm{~min}$ at $4^{\circ} \mathrm{C}$. After the addition of four volumes of deionized water and vigorous

182 vortexing, samples were centrifuged at $3,500 \times \mathrm{g}$ for $10 \mathrm{~min}$ at $4^{\circ} \mathrm{C}$. The upper phase

183 was removed and proteins precipitated by adding 3 volumes of methanol and

184 centrifuging at 3,500 $\mathrm{x} g$ for $4 \mathrm{~min}$. The pellets were then resuspended in solubilization

185 buffer. The second dimension electrophoresis was run at $11 \mathrm{~mA} / \mathrm{gel}$ for $15 \mathrm{~h}$ at $4^{\circ} \mathrm{C}$.

186 Image analysis. Spots were detected and their volume quantified with Prodigy

187 SameSpots software (Nonlinear Dynamics), analyzing images of at least three gels for

each time and condition. A sample taken at time zero (just before water/ethanol addition) was chosen as the . Protein expression was deemed to have changed if the mean normalized spot volume varied at least twofold and was confirmed by analysis of variance at a significant level of $P<0.05$. Reproducibility was assessed by performing three independent experiments, and sets of five gels were analyzed.

Identification of proteins by peptide mass fingerprinting. Individual spots were excised from the gels and submitted to tryptic digestion, and mass spectrometry analyses were performed as previously described (Guillot et al., 2003). The mass of the peptides was determined by MALDI-TOF MS on a Voyager DE STR instrument (Applied Biosystems) at the PAPSSO platform of the INRA Center in Jouy-en-Josas. Proteins were identified against the $O$. oeni NC_008528 database. 
200

201

202

203

204

205

206

207

208

209

210

211

212

213

214

215

216

217

218

219

220

221

222

223

\section{Results and Discussion}

Functional analysis using comparative transcriptomics and proteomics could provide insight into stress responses and regulation mechanisms in O. oeni. Our main aim was to evaluate which genes and proteins are most affected by ethanol shock.

The growth of $O$. oeni PSU-1 in MRS medium and the effect of ethanol on population development were monitored by counting plates (data not shown). In all conditions, the population remained constant during the 3-hour assay, and cell populations of more than $10^{7} \mathrm{CFU} \mathrm{ml}^{-1}$ were detected.

\subsection{Transcriptional profiling after ethanol shock}

Transcriptional analysis was carried out using mRNA from the control (water addition) at $\mathrm{t}=0 \mathrm{~h}$ or at $\mathrm{t}=1 \mathrm{~h}$, and mRNA from ethanol treated samples at $\mathrm{t}=1 \mathrm{~h}$ and $\mathrm{t}=3 \mathrm{~h}$. The rough data were first analyzed to get an indication of reproducibility, and spot intensities were compared between pairs of filters. Scatter plots of normalized spot intensities (arbitrary units) from 1611 individual spots were generated and showed good reproducibility between filters (Figure 1A is a representative example). Averaged spot intensities from a sample taken at $\mathrm{t}=0 \mathrm{~h}$ versus $\mathrm{t}=1 \mathrm{~h}$ after water addition (control) show a better correlation (Figure 1B) than the ethanol-treated samples (Figure 1, C and D).

In order to validate the results obtained from the microarray analysis, real-time qPCR was performed with the same RNA from the original microarray experiment. Eleven genes, some related to stress response, were selected: $n a d E, c a n H, p y r B, h s p 18$, trhD, amt, citE, atpB, qnnR, mleA-2 and mleR. There was a general accordance between microarray and real-time qPCR data for all the genes tested (Table 2). Of the eleven genes, eight were clearly correlated using both techniques. The three remaining genes $(c a n H, c i t E, m l e R)$ displayed lower numerical values by microarray, indicating no 
225 significant changes through this technique. Overall, the correlation between real-time

226 qPCR and microarray was good, suggesting that the microarray gene expression

227 measurements were valid.

228 Transcriptomic data were grouped by functional categories in order to identify

229 biological processes influenced by ethanol shock. Time zero, just before water/ethanol

230 addition, was used as the reference condition to normalize data. In the control condition

231 (water addition) some genes decreased their expression, probably due to changes in

232 nutrient concentration (data not shown). However, the greatest changes in gene

233 expression were observed for ethanol addition. Table 3 shows the number of genes from

234 each functional category with altered expression in samples obtained one hour after the

235 addition of $12 \%$ ethanol $(\mathrm{t}=1 \mathrm{~h})$. The presence of ethanol appeared to influence gene

236 expression in a wide range of functional classes. A total of 1611 genes were detected by

237 the microarray. Of these, 170 genes decreased their expression after ethanol shock and

23830 genes increased their expression in the presence of ethanol. Some groups seemed to

239 be less affected by ethanol (cell mobility and secretion, coenzyme metabolism,

240 secondary metabolites and signal transduction mechanisms), while others were more

241 affected (amino acid transport and metabolism, cell envelope biogenesis in the outer

242 membrane and transcription). Transcriptomic data analysis was also performed in

243 samples obtained 3 hours after ethanol addition $(t=3 \mathrm{~h})$, but no significant difference was

244 observed in comparison with $\mathrm{t}=1 \mathrm{~h}$ samples (data not shown).

245 Table 4 shows the transcriptomic analysis of the relative expression of the genes

246 between time zero and 1 hour after the addition of $12 \%$ ethanol. The table shows all up-

247 regulated genes with known functions. A selection of the most inhibited genes has also

248 been included for each functional category. Microarray data revealed that transport

249 systems were widely inhibited in response to ethanol shock. In particular, permeases 
250 involved in metabolite transport, such as amino acids and carbohydrates, and inorganic

251 ions were down-regulated.

252

As far as amino acid transport is concerned, it should be pointed out that five of

253 the seven genes encoding for amino acid permeases that were down-regulated are

254 related to glutamate and/or gamma-aminobutyrate transport (GABA). The other two

255 genes are generic amino acid transporters. Gene OEOE_1747 encoding a possible

256 GABA permease showed one of the strongest inhibitions (sevenfold). The

257 glutamate/GABA antiporter (OEOE_0883) was also down-regulated in response to

258 ethanol. Other inhibited amino acid transporter genes (OEOE_1806, OEOE_1427,

259 OEOE_0388) showed high homology with orthologue glutamate/GABA transport genes

260 in other LAB species (data not shown). It has been reported that the conversion of 261 glutamate into GABA may confer resistance to bacterial cells, including some LAB

262 species, under acidic conditions because of the consumption of an intracellular proton in

263 the reaction (Cotter and Hill, 2003). However, the gene of glutamate decarboxylase, the

264 enzyme responsible for GABA production from glutamate, has not been found in $O$.

265 oeni. However, an aminotransferase gene that transforms GABA into succinate

266 semialdehyde and L-glutamate is present in the $O$. oeni PSU-1 genome (OEOE_0387).

267 GABA can be assimilated as a nitrogen and/or carbon source in bacteria such as

268 Escherichia coli (Bartsch et al., 1990) and Corynebacterium glutamicum (Zhao et al.,

269 2012), but no information is available about LAB in this respect. The inhibition of

270 glutamate and GABA transport after ethanol shock observed in this study may account

271 for the cell growth arrest due to stress. Vasserot et al. (2003) described the inability of

272 O. oeni to uptake L-glutamate in non-energy generating cells (membrane potential).

273 Similar findings were described for Lactobacillus casei (Strobel et al., 1989) and

274 Lactococcus lactis (Smid et al., 1989). Two genes involved in the transport of 
275 spermidine/putrescine were down-regulated. Like glutamate transport, the uptake of

276 these two polyamines has been associated with an energy-producing state/membrane

277 potential of the cell in E. coli (Kashiwagi et al., 1997). Both putrescine and spermidine

278 protect against oxidative stress (Tkachenko et al., 2001). This protective mechanism

279 may also be a target of ethanol damage, which inhibits the uptake of these polyamines.

280 In contrast to the previously mentioned down-regulated functions, a dipeptidase $A$ gene

281 (OEOE_1783) was over-expressed in response to ethanol. This is in line with the

282 increase in protease or peptidase activity in response to stress reported by other authors

283 (Manca de Nadra et al., 1999; Ritt et al., 2008).

Multiple genes involved in carbohydrate transport were negatively affected,

which may partly explain the decrease in energy production that led to the arrest of the nitrogenated-compound transport mentioned above. Only an ATPase (OEOE_1456) related to sugar transport was induced after ethanol shock. However, other ATPase components related to defense mechanisms were inhibited (OEOE_0722 and OEOE_0735).

Some genes related to cell wall and membrane biogenesis were also significantly affected. The most inhibited were two genes with acetyl transferase function. The gene encoding for a rod shape-determining protein (MreB) was inhibited threefold. This protein has been reported to have a cytoskeletal, actin-like role in bacterial cell morphogenesis and seems to be essential for cell survival since its deletion causes inflated morphology and, finally, cell lysis (Jones et al., 2001). These transcriptional changes are indicative of cell envelope damage due to ethanol action. However, the down-regulation of several $\mathrm{N}$-acetylmuramidase genes (OEOE_0735, OEOE_0588, 
299 weakening since these genes encode for proteins with autolysin activity (Delcour et al.,

300

301

302

303

304

305

306

307

308

309

310

311

312

313

314

315

316

317 1999; Govindasamy-Lucey et al., 2000).

Gene expression related to defense mechanisms, DNA replication, recombination, repair and transcription was widely affected after ethanol shock (Table 4). Among the genes inhibited under these functional categories were multidrug and antimicrobial ATPase and transport systems. Several transcriptional regulators were also significantly down-regulated - for example, various members of the xenobiotic responsive element (xre) family (OEOE_0047) - but no information is available regarding their activator/repressor role.

Altogether, it seems that ethanol shock triggers the transcriptional inhibition of several cell defense mechanisms in response to the immediate effect of an external threat to the cell, such as the presence of ethanol. Presumably the ability to recover and reactivate these cell protection mechanisms is part of the adaptation response that allows O. oeni strains to survive under wine conditions (Beltramo et al., 2006; Olguín et al., 2009). Meanwhile, the activation of the widely studied stress protein Hsp20 in O. oeni (Guzzo et al., 1997; 2000) confirms the importance of this gene as a marker of stress response in O. oeni.

\subsection{Changes in proteins of $\mathrm{O}$. oeni in response to ethanol shock}

Changes in O. oeni soluble proteome were followed for the first five hours after $12 \%$ ethanol shock. The protein profile of $O$. oeni $\mathrm{PSU}-1$ at $\mathrm{t}=0 \mathrm{~h}$ was characterized to generate a standard grid, which was used for subsequent comparative studies of samples obtained after water/ethanol addition. The high-resolution map that was obtained revealed approximately 215 spots (Fig. 2A), indicating a better resolution than in a 
323 previous study (Silveira et al., 2004). A larger quantity of spots was detected by

324 Cecconi et al. (2009), even though they used a larger gradient (pH 3-10). patterns that could be recognized by simple visual comparison of the two conditions. Further analysis of the gels confirmed that ethanol-treated and control populations $(12 \%$ water addition) had different responses. Two spots decreased their intensity in the control condition. One of these spots could not be identified; the other was spot 7, which also diminished in the ethanol-treated samples (Fig. 2A). After ethanol treatment, intensity increased in one spot (spot 36) and decreased in 44. This is in agreement with a previous report in which most proteins decreased in concentration after ethanol shock (Silveira et al., 2004).

Of the 45 spots found in different quantities when compared to the proteome reference gel $(t=0 h), 35$ were identified, corresponding to 31 different proteins (Table 5). Unfortunately spot 36 (Fig. 2B), the only one detected that increased in response to ethanol shock, could not be identified.

As shown in Table 5, the proteins identified are involved mainly in nucleotide transport and metabolism (22.86\%), translation, ribosomal structure and biogenesis (17.14\%), cell envelope biogenesis (14.26\%) and posttranslational modification, protein turnover and chaperone functions (11.43\%). Seven spots were classified in five other functional categories and for the last five spots (14.29\%) no function could be predicted. Three proteins (PyrG, PyrE and Zwf) matched two different spots (spots 1 and 2, posttranslational modifications that affect their $p I$ and/or mass. 
As mentioned above, image analysis showed only subtle changes in the protein

kinetics in the control assay with added water. Therefore all further analysis focused on the gels obtained from the ethanol-treated cultures. The fold-change value was derived from the mean normalized volumes of four groups of three gels, each group corresponding to $\mathrm{t}=0 \mathrm{~h}$ (reference gel), 1,3 and $5 \mathrm{~h}$. Fold-changes between control at $\mathrm{t}=0 \mathrm{~h}$ and ethanol-treated samples at $\mathrm{t}=5 \mathrm{~h}$ are indicated in Table 5 . On the basis of their predicted function, proteins were classified into ten different functional categories.

The kinetic changes were also analyzed and seven different patterns observed. category, several kinetics were observed; for instance, spots 2 (PyrG) and 7 (PyrE) both belong to the pyrimidine biosynthetic pathway. These patterns of expression suggest a complex response to ethanol during the first 5 hours of exposure (Fig. 2B). Indeed, one protein (spot 36) increased after one hour and then remained stable, whereas other spots decreased after one hour and remained stable (spots 7 and 23), or decreased only after 3 hours (spots 2, 11, 27), or showed a gradual decrease over time (spots 11 and 21). However, we were unable to find a clear-cut link between functional categories and the type of kinetics.

Our results suggest that protein synthesis and stability decrease when cells are directly submitted to $12 \%$ ethanol since more than half the proteins $(53.13 \%)$ that decrease in concentration are related to these protective functions. The concentration of

367 the molecular chaperone DnaK, a stress-induced protein in several lactic acid bacteria 368 (Kilstrup et al., 1997; Lim et al., 2000), decreases after ethanol shock (Table 5). This decrease in DnaK concentration in the cytosolic fraction may be related to the recruitment of this chaperone to the membrane, as described for Bacillus subtilis DnaK after short-term ethanol stress (Seydlova et al., 2012). A similar phenomenon of 
372 membrane association has been described for heat shock protein Lo18 in $O$. oeni

373 (Weidmann et al., 2010). It has been widely reported that $O$. oeni cells respond to the

374 presence of ethanol by decreasing the fluidity of their membranes (Da Silveira et al.,

375 2003; Chu-Ky et al., 2005). It has also been suggested that this decrease in fluidity

376 stems from the changed lipid-to-protein ratio, which plays an important role in

377 regulating fluidity. The recruitment of several stress proteins to the membrane could

378 play a protective role of protein stabilization and membrane fluidity regulation, as 379 described for Lo18 (Weidmann et al., 2010).

Other stress proteins such as $\mathrm{ClpC}$ and $\mathrm{ClpE}$ also diminish in the presence of ethanol. These two proteins have ATPase activity and can function either as molecular chaperones or as regulating components of a proteolytic complex by associating to ClpP protease (Beltramo et al., 2004). Therefore this association of each of the ATPases with ClpP to form a two-subunit complex in response to ethanol stress may account for the decrease in the cytosolic fraction of these proteins in the single form.

About $14 \%$ of the proteins that decrease in concentration are related to cell envelope biogenesis. One of them, identified as dTDP-D-glucose 4,6-dehydratase ( RmlB), is involved in cell wall lipopolysaccharide biosynthesis. In the proteomic study by Silveira et al. (2004), RmlB was detected in the membrane-associated protein extract of cells pre-adapted in $8 \%$ ethanol but not in the control condition or after 1 hour of $12 \%$ ethanol shock. In our study RmlB was present in all the samples, although it decreased over time in the presence of ethanol. This suggests that $r m l B$ is initially down-regulated after ethanol shock, which decreases the RmlB protein level, but is subsequently over-expressed when cells are adapted and so may be an indicator of cell acclimation. We have also observed that in some $O$. oeni strains there is a correlation between high levels of $r m l B$ transcripts and a better malolactic performance (Olguín et 
397 al., 2010). The present study also shows that proteins such as MurC, MurD and GlmS, which are involved in murein biosynthesis, are down-regulated after a $12 \%$ ethanol shock (Table 5). Altogether, these results suggest that ethanol stress causes important changes in cell wall composition. It is clear that resistance to stress depends on the

401 genes involved in peptidoglycan and teichoic acid biosynthesis (Delcour et al., 1999). Nonetheless, there is little biochemical or genetic data available on the biosynthesis pathways of the cell wall constituents in lactic acid bacteria. Further study is required in this area.

\subsection{Global evaluation of transcriptomic and proteomic changes}

Little correlation has been found among the 31 identified proteins changing in abundance and with their gene expression analyzed by microarray. Only two genes, lactoylglutathione lyase (OEOE_0531) and glucosamine 6-phosphate aminotransferase (OEOE_0635), showed the same behavior at protein and gene level; in both cases their expression decreased after ethanol addition. These two genes could therefore be useful molecular reporters of the metabolic state of cells in response to ethanol stress. Cecconi et al. (2009) reported a similar result for one of these proteins, glucosamine 6-phosphate aminotransferase (OEOE_0635), which was less abundant in cells not acclimated to ethanol (as in the present study) than in acclimated cells. Thus we might suggest that the non-activation of these genes indicate cellular metabolic robustness against the induced stress.

The other proteins that decreased in concentration showed no changes in gene expression. These differences may be accounted for by posttranscriptional regulation, changes in protein localization and, most probably, protein degradation due to ethanol damage. However, a considerable number of the genes that are differentially expressed, 
422 according to transcriptomic analysis, encode for membrane-associated proteins (e.g.

423 permeases), whereas in this work only the soluble proteome was analyzed. Nonetheless,

424 the combination of both transcriptomic and proteomic approaches confirmed the

425 functions that are mainly affected by short-term ethanol stress in $O$. oeni.

In conclusion, the transport of metabolites and cell wall and membrane

427 biogenesis are the main functional categories affected by ethanol shock. These results

highlight the importance of the membrane as a barrier to stress and as a key element for

cell protection. One of the mechanisms of response to cell damage is the recruitment of

several stress proteins to the membrane. This is the first study to present a

transcriptomic analysis of $O$. oeni and to combine this data with a proteomic analysis.

432 This dual approach opens the door to future studies on the behavior of $O$. oeni under

433 wine-related conditions.

\section{Acknowledgments}

This work was supported by grants AGL2006-03700ALI and AGL2009fellowship and to the Spanish Ministry of Education for a mobility grant (TME2008-

01339). Nair Olguín would also like to thank Dr Christian Beauvallet (INRA, Jouy-en-

Josas, France) for his support and collaboration in the protein electrophoresis analyses.

\section{References}

444 Bartsch, K., von Johnn-Marteville, A., Schulz, A., 1990. Molecular analysis of two 445 genes of the Escherichia coli gab cluster: nucleotide sequence of the glutamate:succinic semialdehyde transaminase gene ( $g a b T)$ and characterization of 
447 the succinic semialdehyde dehydrogenase gene ( $g a b D)$. Journal of Bacteriology 172, $448 \quad 7035-7042$.

449 Beltramo, C., Grandvalet, C., Pierre, F., Guzzo, J., 2004. Evidence for multiple levels of 450 regulation of Oenococcus oeni clpP-clpL locus expression in response to stress. 451 Journal of Bacteriology 186, 2200-2205.

452 Beltramo, C., Desroche, N., Tourdot-Marechal, R., Grandvalet, C., Guzzo, J., 2006. 453 Real-time PCR for characterizing the stress response of Oenococcus oeni in a wine$454 \quad$ like medium. Research Microbiology 157, 267-274.

455 Beney, L., Gervais, P., 2001. Influence of the fluidity of the membrane on the response 456 of microorganisms to environmental stresses. Applied Microbiology and Biotechnology 57, 34-42.

458 Capucho, I., San Romão, M.V., 1994. Effect of ethanol and fatty acids on malolactic 459 activity of Leuconostoc oenos. Applied Microbiology and Biotechnology 42, 391460 395.

Cafaro, C., Bonomo, M.G., Salzano,G., 2014. Adaptative changes in geranylgeranyl pyrophosphate synthase gene expression level under ethanol stress conditions in

Cecconi, D., Milli, A., Rinalducci, S., Zolla, L., Zapparoli, G., 2009. Proteomic analysis 465 2995.

468 Cotter, D., Hill, C., 2003. Surviving the acid test: Responses of Gram-positive bacteria to low pH. Microbiology and Molecular Biology Reviews 63(3), 429-453. 
472 transport system in Oenococcus oeni during rehydration. Applied Microbiology and

$473 \quad$ Biotechnology 91, 1601-1609.

474 Champomier-Vergès, M.C., Maguin, E., Mistou, M.Y., Anglade, P., Chich, J.F., 2002.

475 Lactic acid bacteria and proteomics: current knowledge and perspectives. Journal of $476 \quad$ Chromatography 771, 329-342.

477 Chu-Ky, S., Tourdot-Maréchal, R., Marechal, P.A., Guzzo, J., 2005. Combined cold, 478 acid and ethanol shocks in Oenococcus oeni: effects on membrane fluidity and cell 479 viability. Biochimica and Biophysica Acta 1717, 118-124.

480 Da Silveira, M.G., Golovina, E.A., Hoekstra, F.A., Rombouts, F.M., Abee, T., 2003. 481 Membrane fluidity adjustments in ethanol-stressed Oenococcus oeni cells. Applied 482 and Environmental Microbiology 69(10), 5826-5832.

483 Davis, C.R., Wibowo, D., Eschenbruch, R., Lee, T.H., Fleet, G.H., 1985. Practical 484 implications of malolactic fermentation: a review. American Journal of Enology and $485 \quad$ Viticulture 36(4), 290-301.

486 Delcour, J., Ferain, T., Deghorain, M., Palumbo, E., Hols, P., 1999. The biosynthesis 487 and functionality of the cell-wall of lactic acid bacteria. Antonie Van Leewenhoek $76,159-184$.

De Man, J.C., Rogosa, M., Sharpe, M.E., 1960. A medium for the cultivation of 490 lactobacilli. Journal of Applied Bacteriology 23, 130-135.

491 Desroche, N., Beltramo, C., Guzzo, J., 2005. Determination of an internal control to apply reverse transcription quantitative PCR to study stress response in the lactic acid bacterium Oenococcus oeni. Journal of Microbiology Methods 60, 325-333.

494 Govindasamy-Lucey, S., Gopal, P.K., Sullivan, P.A., Pillidge, C.J., 2000. Varying 495 influence of the autolysin, $\mathrm{N}$-acetyl muramidase, and the cell envelope proteinase on 
the rate of autolysis of six commercial Lactococcus lactis cheese starter bacteria grown in milk. Journal of Dairy Research 67, 585-96.

498 Guillot, A., Gitton, C., Anglade, P., Mistou, M.Y., 2003. Proteomic analysis of $499 \quad$ Lactococcus lactis, a lactic acid bacterium. Proteomics 3, 337-354.

500 Guzzo, J., Delmas, F., Pierre, F., Jobin, M.P., Samyn, B., Van Beeumen, J., Cavin, J.F., 501 Diviès, C., 1997. A small heat shock protein from Leuconostoc oenos induced by multiple stresses and during stationary growth phase. Letters in Applied Microbiology 24, 393-396.

504

Guzzo, J., Jobin, M.P., Delmas, F., Fortier, L.C., Garmyn, D., Tourdot-Marechal, R.,

Lee, B., Divies, C., 2000. Regulation of stress response in Oenococcus oeni as a function of environmental changes and growth phase. International Journal of Food Microbiology 55, 27-31.

Irizarry, R.A., Bolstad, B.M., Collin, F., Cope, L.M., Hobbs, B., Speed, T.P., 2003a. Summaries of Affymetrix GeneChip probe level data. Nucleic Acid Research 31, e15.

Irizarry, R.A., Hobbs, B., Collin, F., Beazer-Barclay, Y., Antonellis, K.J., Scherf, U., Speed, T.P., 2003b. Exploration, Normalization, and Summaries of High Density Oligonucleotide Array Probe Level Data. Biostatistics 4, 249-264.

Jones, L.J., Carballido-Lopez, R., Errington, J., 2001. Control of cell shape in bacteria: helical, actin-like filaments in Bacillus subtilis. Cell 104, 913-922.

516 Kashiwagi, K., Shibuya, S., Tomitori, H., Kuraishi, A., Igarashi, K., 1997. Excretion 517 and uptake of putrescine by the PotE protein in Escherichia coli. The Journal of 518 Biological Chemistry 272(10), 6318-6323. 
519 Kilstrup, M., Jacobsen, S., Hammer, K., Vogensen, F.K., 1997. Induction of heat shock

520 proteins DnaA, GroEL, and GroES by salt stress in Lactococcus lactis. Applied and $521 \quad$ Environmental Microbiology 63(5), 1826-1837.

522 Lim, E.M., Ehrlich, S.D., Maguin, E., 2000. Identification of stress-inducible proteins in $523 \quad$ Lactobacillus delbrueckii subsp. bulgaricus. Electrophoresis 21, 2557-2561.

524 Livak, K.J., Schmittgen, T.D., 2001. Analysis of relative gene expression data using 525 real-time quantitative PCR and the 2- $\Delta \Delta \mathrm{CT}$ method. Methods $25,402-408$.

526 Malherbe, S., Bauer, F.F., Du Toit, M., 2007. Understanding problem fermentations - A

527 review. South African Journal of Enology and Viticulture 28(2), 169-186.

528 Manca de Nadra, M.C., Farias, M., Moreno-Arribas, M.V., Pueyo, E., Polo, M.C., 1999.

529 A proteolytic effect of Oenococcus oeni on the nitrogenous macromolecular fraction 530 of red wine. FEMS Microbiology Letters 174, 41-47.

531 Olguín, N., Bordons, A., Reguant, C., 2009. Influence of ethanol and pH on the gene 532 expression of the citrate pathway in Oenococcus oeni. Food Microbiology 26, 197533203

534 Olguín, N., Bordons, A., Reguant, C., 2010. Multigenic expression analysis as an 535 approach to understanding the behaviour of Oenococcus oeni in wine-like conditions. International Journal of Food Microbiology 144, 88-95.

537 Pieterse, B., Leer, R.J., Schuren, F.H.J., van der Werf, J., 2005. Unravelling the multiple 538 effects of lactic acid stress on Lactobacillus plantarum by transcription profiling. $539 \quad$ Microbiology 151, 3881-3894.

540 Ritt, J.F., Guilloux-Benatier, M., Guzzo, J., Alexandre, H., Remize, F., 2008. 541 Oligopeptide assimilation and transport by Oenococcus oeni. Journal of Applied $542 \quad$ Microbiology 104, 573-580. 
543 Salema, M., Lolkema, J., San Romão, M.V., Loureiro Dias, M.C. 1996. The proton

544 motive force generated in Leuconostoc oenos by L-malate fermentation. Journal of $545 \quad$ Bacteriology 178(11), 3127-3132.

546 Sánchez, B., Champomier-Vergès, M.C., Anglade, P., Baraige, F., Reyes-Gavilán, C.G.,

547 Margolles, A., Zagorec, M., 2005. Proteomic analysis of global changes in protein 548 expression during bile salt exposure of Bifidobacterium longum NCIMB 8809. $549 \quad$ Journal of Bacteriology 187(16), 5799- 5808.

550 Seydlová, G., Halada, P., Fišer, R., Toman, O., Ulrych, A., Svobodová, J., 2012. DnaK 551 and GroEL chaperones are recruited to Bacillus subtilis membrane after short-term ethanol stress. Journal of Applied Microbiology 112, 765-774.

553 Siezen, R.J., van Enckevort, F.H.J., Kleerebezem, M., Teusink, B., 2004. Genome data mining of lactic acid bacteria: the impact of bioinformatics. Current Opinion in Biotechnology 15, 105-115.

Silveira, M.G., Baumgartner, M., Rombouts, F.M., Abee, T., 2004. Effect of adaptation on cytoplasmic and membrane protein profiles of Oenococcus oeni. Applied and Environmental Microbiology 70 (5), 2748-2755.

559 Smid, E.J., Driessen, A.J., Konings, W.N., 1989. Mechanism and energetics of dipeptide transport in membrane vesicles of Lactococcus lactis. Journal of Bacteriology 171, 292-298.

562 Strobel, H.J., Russell, J.B., Driessen, A.J.M., Konings, W.N., 1989. Transport of amino acids in Lactobacillus casei by proton-motive-force-dependent mechanisms. American Society for Microbiology 171(1), 280-284.

Sumby, K.M., Grbin, P.R., Jiranek, V., 2012. Validation of the use of multiple internal 566 control genes, and the application of real-time quantitative PCR, to study esterase 
567 gene expression in Oenococcus oeni. Applied Microbiology and Biotechnology, 568 96(4), 1039-1047.

569 Tkachenko, A.G., Pshenichnov, M.R., Nesterova, L.Y., 2001. Putrescine as a factor 570 protecting Escherichia coli against oxidative stress. Microbiology 70(4), 422-428.

571 Vandesompele, J., De Preter, K., Pattyn, F., Poppe, B., Van Roy, N., De Paepe, A., 572 Speleman, F., 2002. Accurate normalization of real-time quantitative RT-PCR data 573 by geometric averaging of multiple internal control genes. Genome Biology 3(7), 1$574 \quad 12$

575 Vasserot, Y., Dion, C. Bonnet, E., Tabary, I., Maujean, A., Jeandet, P., 2003. Transport 576 of glutamate in Oenococcus oeni 8403. International Journal of Food Microbiology $577 \quad 85,307-311$.

578 Versari, A., Parpinello, G.P., Cattaneo, M., 1999. Leuconostoc oenos and malolactic 579 fermentation in wine: a review. Journal of Industrial Microbiology and $580 \quad$ Biotechnology 23, 447-455.

581 Weber, F.J., Bont, J.A.M., 1996. Adaptation mechanisms of microorganisms to the 582 toxic effects of organic solvents on membranes. Biochimica and Biophysica Acta $583 \quad 1286,225-245$.

584 Weidman, S., Rieu, A., Rega, M., Coucheney, F., Guzzo, J., 2010. Distinct amino acids 585 of the Oenococcus oeni small heat shock protein Lo18 are essential for damaged 586 protein protection and membrane stabilization. FEMS Microbiology Letters 309, 8$587 \quad 15$.

588 Zhao, Z., Ding, J-Y., Ma, W-H., Zhou, N-Y., Liu, S-J., 2012. Identification and 589 characterization of $\gamma$-aminobutyric acid uptake system $\mathrm{GabP}_{C g}(\mathrm{NCg10464)}$ in 590 Corynebacterium glutamicum. Applied and Environmental Microbiology 78, 25965912601. 
592

$593 \quad$ Figure legends

594

595 Figure 1. Scatter plots of normalized spot intensities (arbitrary units) from 1611

596 individual spots. A) Typical replicates showing the intensity of each spot versus the 597 equivalent spot in a replicate filter. B), C) and D) Averaged spot intensities from a 598 sample taken at $\mathrm{t}=0 \mathrm{~h}(X$-axis $)$ versus ethanol-treated and control samples $(Y$-axis $) . \mathrm{t}=$ $5991 \mathrm{~h} \mathrm{H}_{2} \mathrm{O}$ (control condition): one hour after water addition; $\mathrm{t}=1 \mathrm{~h} \mathrm{EtOH}$; one hour after 600 ethanol addition; $\mathrm{t}=3 \mathrm{~h} \mathrm{EtOH}$ : three hours after ethanol addition. Asterisks indicate 601 significant differences (one-way analysis of variance (ANOVA) and the Bonferroni 602 post-test, $P<0.05)$.

603

604 Figure 2. A) Reference map of proteins extracted from $O$. oeni PSU-1 cells in the late605 exponential phase of growth in MRS ( $\mathrm{t}=0 \mathrm{~h})$ before water or ethanol addition. The 606 differentially expressed spots are indicated by spot number as reported in Table 5. B)

607 Kinetics of expression of some spots of representative proteins at time 0 , and 1, 3, and 6085 h (columns) after ethanol shock. N.Vol., normalized volumes. 

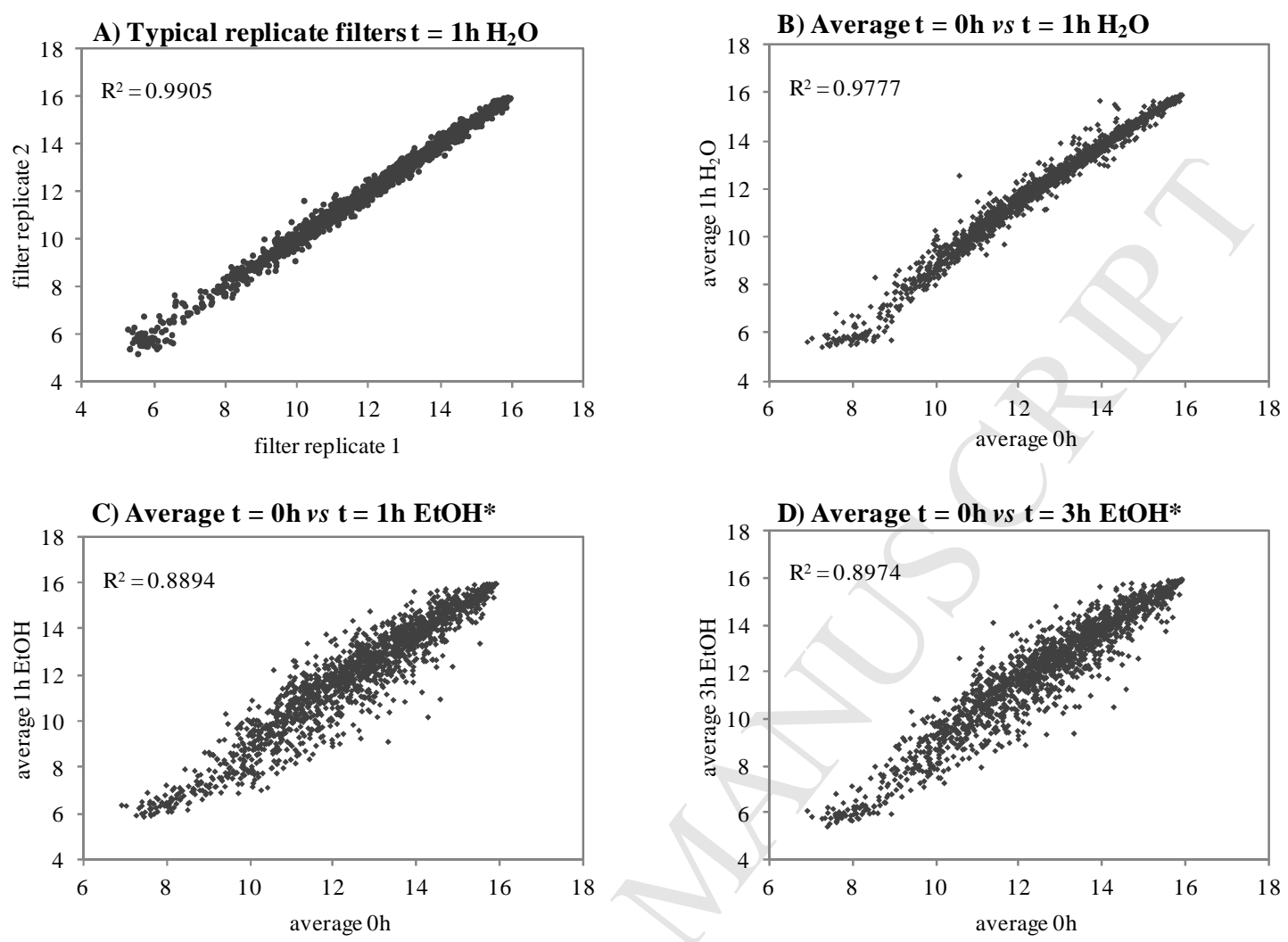

Figure 1. Scatter plots of normalized spot intensities (arbitrary units) from 1611 individual spots. A) Typical replicates showing the intensity of each spot versus the equivalent spot in a replicate filter. B), C) and D) Averaged spot intensities from a sample taken at $\mathrm{t}=0 \mathrm{~h}(X$-axis) versus ethanol-treated and control samples $(Y$-axis $) ; \mathrm{t}=$ $1 \mathrm{~h} \mathrm{H}_{2} \mathrm{O}$ (control condition): one hour after water addition; $\mathrm{t}=1 \mathrm{~h} \mathrm{EtOH}$ : one hour after ethanol addition; $\mathrm{t}=3 \mathrm{~h} \mathrm{EtOH}$ : three hours after ethanol addition. Asterisks indicate significant differences (one-way analysis of variance (ANOVA) and the Bonferroni post-test, $P<0.05)$. 

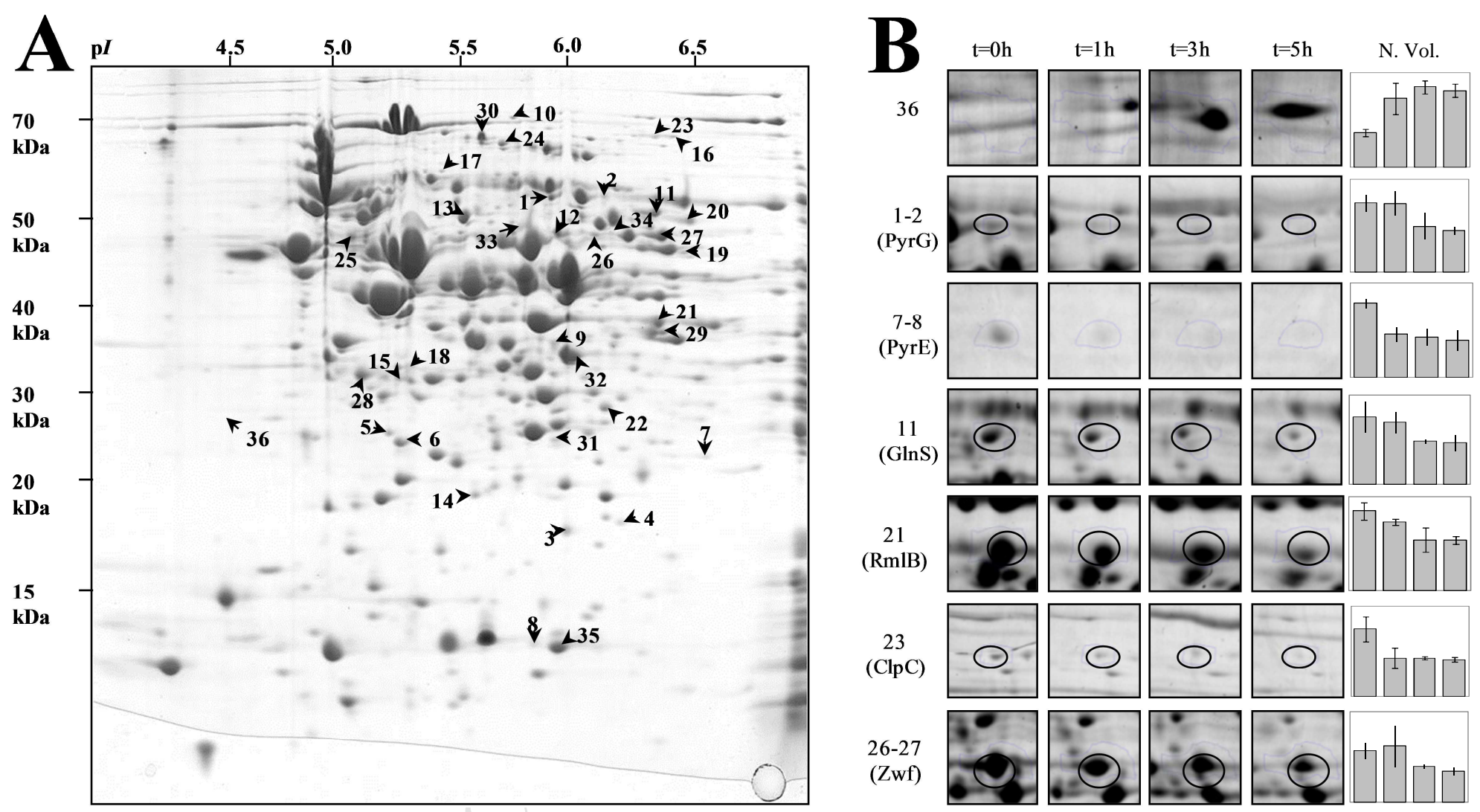

Figure 2. A) Reference map of proteins extracted from $O$. oeni PSU-1 cells in the late-exponential phase of growth in MRS before water or ethanol addition $(\mathrm{T}=0 \mathrm{~h})$. The differentially expressed spots are indicated by spot number as reported in Table 5. B) Kinetics of expression of some spots of representative proteins at time 0 , and 1,3 , and $5 \mathrm{~h}$ after ethanol shock. N.Vol., normalized volumes. 
Table 1. Primers used for real-time qPCR analysis

\begin{tabular}{|c|c|c|c|c|c|}
\hline $\begin{array}{c}\text { Target } \\
\text { gene }\end{array}$ & Description & Forward primer $\left(5^{\prime} \rightarrow 3^{\prime}\right)$ & Reverse primer $\left(5^{\prime} \rightarrow 3^{\prime}\right)$ & $\begin{array}{l}\text { Amplicon } \\
\text { length (bp) }\end{array}$ & Reference \\
\hline nadE & OEOE_0008 NH(3)-dependent NAD(+) synthetase & AACATGACGGCGTTGTTC & GATCCAAATCGGTTCCTCCATC & 93 & This study \\
\hline $\mathrm{canH}$ & OEOE_0238 carbonic anhydrase & CATGCTCCCAGTGAACATC & CAGCGATAACTGCTGTTCTTCC & 97 & This study \\
\hline pyr $B$ & OEOE_0258 pyrB aspartate carbamoyltransferase & GGCAGGTTGTTGCCAATC & TTGTTGCCGAGGACTTGTTGGG & 123 & This study \\
\hline hsp18 & OEOE_0289 heat shock protein Hsp20 & CGGTATCAGGAGTTTTGAGTTC & CGTAGTAACTGCGGGAGTAATTC & 102 & Beltramo et al. 2006 \\
\hline $\operatorname{trh} D$ & OEOE_0394 threonine dehydrogenase & AGAGTTCTTGCGCGAGAC & CCGGTGCCACTCATATTCTTAG & 114 & This study \\
\hline amt & OEOE_0411 aminotransferase & TTGGACAGCGAAGGAAGAGT & GTTTATCTTCGGCCGTCAAC & 94 & This study \\
\hline$c i t E$ & OEOE_0422 Citrate lyase beta subunit & CCGCACGATGATGTTTGTTCC & GCTCAAAGAAACGGCATCTTCC & 108 & Olguín et al. 2009 \\
\hline $\operatorname{atp} B$ & OEOE_0665 F0F1-type ATP synthase, beta subunit & ATACTGATCCGGCTCCGGC & CAGCGGGATAAATACCTTG & 93 & Beltramo et al. 2006 \\
\hline$q n n R$ & OEOE_1290 NADPH:quinone reductase & GCAGCTTGCCCTAATTCC & CCTTGATAATCGCCTGGTATCC & 92 & This study \\
\hline$m l e A-2$ & OEOE_1325 malate dehydrogenase (NAD) & AGGCCATGTCGGATCAAC & CAAGTGCGTCCGCTTTGA & 107 & This study \\
\hline mleR & OEOE_1565 MLF system transcription activator & GGCAACCCTGGAATTGAG & CTGATCGAAGACGCTGTTG & 130 & This study \\
\hline$l d h D$ & D-lactate dehydrogenase & GCCGCAGTAAAGAACTTGATG & TGCCGACAACACCAACTGTTT & 102 & Desroche et al. 2005 \\
\hline
\end{tabular}


Table 2. Validation of microarray data by real-time qPCR

\begin{tabular}{lcc}
\hline Gene name (code) & Microarray $^{\mathrm{a}}$ & $\mathrm{qPCR}^{\mathrm{b}}$ \\
\hline nadE (OEOE_0008) & +1.92 & +1.71 \\
canH (OEOE_0238) & +0.08 & +2.99 \\
pyrB (OEOE_0258) & +3.12 & +6.92 \\
hsp18 (OEOE_0289) & +2.04 & +1.64 \\
trhD (OEOE_0394) & +3.18 & +4.50 \\
amt (OEOE_0411) & +2.50 & +6.11 \\
citE (OEOE_0422) & +0.99 & +2.11 \\
atpB (OEOE_0665) & +0.10 & +0.52 \\
qnnR (OEOE_1290) & +3.72 & +2.91 \\
mleA-2 (OEOE_1325) & +2.54 & +3.84 \\
mleR (OEOE_1565) & -0.40 & +4.44 \\
\hline${ }^{\mathrm{a}}$ Microarray and ${ }^{\mathrm{b}} \mathrm{RT}$-qPCR fold changes between: $\mathrm{t}=0 \mathrm{~h}$ and $\mathrm{t}=1 \mathrm{~h}$ after ethanol addition.
\end{tabular}


Table 3. Number of genes of Oenococcus oeni PSU-1 with altered expression $1 \mathrm{~h}$ after ethanol addition according to functional group.

\begin{tabular}{lcc}
\hline Functional Group & Decreased & Induced \\
\hline Amino acid transport and metabolism & 15 & 1 \\
Carbohydrate transport and metabolism & 12 & 1 \\
Cell envelope biogenesis, outer membrane & 12 & - \\
Cell mobility and secretion & 1 & 1 \\
Coenzyme metabolism & 1 & - \\
Defense mechanisms & 8 & - \\
DNA replication, recombination and repair & 6 & 3 \\
Energy production and conversion & 5 & - \\
Inorganic ion transport and metabolism & 8 & - \\
Intracellular trafficking and secretion & 1 & 1 \\
Lipid metabolism & 7 & 3 \\
Nucleotide transport and metabolism & 1 & 1 \\
Posttranslational modification, protein turnover, chaperones & 3 & 1 \\
Secondary metabolites biosynthesis, transport and catabolism & 2 & - \\
Signal transduction mechanisms & 1 & 1 \\
Transcription & 17 & 1 \\
Translation, ribosomal structure and biogenesis & 7 & 7 \\
General function prediction only & 22 & 9 \\
Function unknown & 41 & 30 \\
\hline Total & 170 & \\
\hline
\end{tabular}


Table 4. Relative expression of genes differentially expressed between $0 \mathrm{~h}$ and $1 \mathrm{~h}$ after ethanol addition. All up-regulated genes with known functions are included (on grey background). Only a selection of the most inhibited genes are included for each functional category.

\begin{tabular}{llc}
\hline${ }^{\mathbf{a}}$ Gene & \multicolumn{1}{c}{${ }^{\mathbf{b}}$ Description } & ${ }^{\mathbf{c}}$ Relative Expression \\
\hline Amino Acid Transport and Metabolism & \\
\hline OEOE 1783 & Dipeptidase A. Cysteine peptidase. MEROPS family C69 & 2.09 \\
OEOE 0394 & Threonine dehydrogenase or related Zn-dependent dehydrogenase & 3.18 \\
OEOE 1747 & Gamma-aminobutyratepermease or related permease & -7.25 \\
OEOE 0634 & Permease of the drug/metabolite transporter (DMT) superfamily & -5.26 \\
OEOE 1806 & ABC-type amino acid transport system. permease and periplasmic & -5.25 \\
& component & \\
OEOE 1465 & Spermidine/putrescine ABC transporter permeaseprotein & -2.65 \\
OEOE 0883 & Glutamate gamma-aminobutyrate antiporter & -2.60 \\
OEOE 0633 & Spermidine/putrescine-binding periplasmic protein & -2.26 \\
OEOE 0632 & Spermidine/putrescine ABC transporter permease protein & -2.05 \\
\hline
\end{tabular}

Carbohydrate Transport and Metabolism

\begin{tabular}{llc}
\hline OEOE 1456 & ABC-type sugar transport system. ATPase component & 2.39 \\
OEOE 0021 & ABC-type sugar transport system. periplasmic component & -4.47 \\
OEOE 1777 & Permease of the major facilitator superfamily & -4.18 \\
OEOE 0023 & ABC-type maltose transport system. permease component & -3.91 \\
OEOE 1574 & Permease of the major facilitator superfamily & -3.53 \\
OEOE 0022 & ABC-type sugar transport system. permease component & -3.01 \\
\hline Cell Envelope Biogenesis. Outer Membrane & \\
\hline OEOE 1497 & Predicted glycosyltransferase & -4.07 \\
OEOE 1851 & O-acetyltransferase family protein & -3.89 \\
OEOE 0288 & D-alanine-activating enzyme & -3.37 \\
OEOE 1388 & Rod shape-determining protein MreD & -3.37 \\
OEOE 0206 & Lyzozyme M1 (1.4-beta-N-acetylmuramidase) & -3.26 \\
\hline
\end{tabular}

Defense mechanisms

\begin{tabular}{lll}
\hline OEOE 0722 & ABC-type multidrug transport system. ATPase component & -8.43 \\
OEOE 0438 & ABC-type antimicrobial peptide transport system. permease \\
& component & -3.34 \\
OEOE 0735 & $\begin{array}{l}\text { ABC-type antimicrobial peptide transport system. ATPase } \\
\text { component }\end{array}$ & -3.21 \\
\hline
\end{tabular}

\section{DNA Replication. Recombination and Repair}

OEOE $1020 \quad$ Rossmann fold nucleotide-binding protein for DNA uptake $\quad-6.15$

OEOE 1019 RNase HII $\quad-3.82$

OEOE 0004 DNA replication and repair protein RecF -3.58 
Energy production and Conversion

\begin{tabular}{llc}
\hline OEOE 0516 & NADH:flavinoxidoreductase. Old Yellow Enzyme family & 2.41 \\
OEOE 0510 & Aryl-alcohol dehydrogenase related enzyme & 2.43 \\
OEOE 0553 & Malate dehydrogenase (NAD) & 2.54 \\
OEOE 0693 & Acetoin reductase & 2.54 \\
OEOE 1046 & NADH:flavinoxidoreductase. Old Yellow Enzyme family & -3.44 \\
OEOE 0168 & Acylphosphatase & -3.33 \\
\hline Inorganic Ion Transport and Metabolism & -4.29 \\
\hline OEOE 1355 & Kef-type K+ transport system. membrane component & -4.25 \\
OEOE 0827 & Mn2+ and Fe2+ transporter of the NRAMP family & -3.96 \\
OEOE 0172 & ABC-type cobalt transport system. permease component CbiQ or & \\
\hline & related transporter & -3.43 \\
\hline OEOE 1087 & ABC-type cobalt transport system. ATPase component & \\
\hline Ontracellular trafficking and secretion & Predicted acyltransferase
\end{tabular}

Lipid Metabolism

\begin{tabular}{llc}
\hline OEOE 0327 & Lipoate-protein ligase & 2.18 \\
OEOE 0881 & Acyl carrier protein phosphodiesterase & -4.07 \\
OEOE 1768 & Esterase/lipase & -3.58 \\
\hline
\end{tabular}

\begin{tabular}{lll}
\hline Nucleotide Transport and Metabolism & \\
\hline OEOE 1543 & $\begin{array}{l}\text { Adenine/guanine phosphoribosyltransferase or related PRPP- } \\
\text { binding protein }\end{array}$ & 2.23 \\
OEOE 0258 & Aspartate carbamoyltransferase & 3.12 \\
OEOE 0635 & Glutamine--fructose-6-phosphate transaminase & -2.82
\end{tabular}

Posttranslational Modification. Protein Turnover. Chaperones

\begin{tabular}{llr}
\hline OEOE 0289 & Heat shock protein Hsp20 & 2.03 \\
OEOE 1639 & Peptidyl-prolylcis-trans isomerase (rotamase) - cyclophilin family & -4.82 \\
OEOE 1062 & Cytochrome bd biosynthesis ABC-type transporter. ATPase and & -3.68 \\
& $\begin{array}{l}\text { permease component }\end{array}$
\end{tabular}

\begin{tabular}{llr}
\hline Secondary metabolite biosynthesis. transport and catabolism & \\
\hline OEOE 0009 & Putative multicopper oxidase & 2.10 \\
OEOE 0547 & Amidase & -3.67 \\
OEOE 0287 & D-alanyl transfer protein & -3.59
\end{tabular}

\begin{tabular}{llc}
\hline Transcription & & \\
\hline OEOE 0411 & $\begin{array}{l}\text { HTH containing DNA-binding domain and MocR-like } \\
\text { aminotransferase }\end{array}$ & 2.51 \\
OEOE 0047 & Transcriptional regulator. xre family & -3.87 \\
OEOE 1830 & Transcriptional regulator. AraC family & -3.49 \\
OEOE 1685 & Transcriptional regulator & -3.43
\end{tabular}


OEOE 0417

Translation. Ribosomal Structure and Biogenesis

\begin{tabular}{llc}
\hline OEOE 1360 & Sigma 54 modulation protein / SSU ribosomal protein S30P & 2.43 \\
OEOE 0950 & tRNA delta(2)-isopentenylpyrophosphatetransferase & -4.37 \\
\hline
\end{tabular}

General Function Prediction Only

OEOE $0531 \quad$ Lactoylglutahionelyase or related lyase $-2.00$

${ }^{\mathrm{a}}$ The gene names are taken from the NCBI database for Oenococcus oeni PSU-1 complete genome

${ }^{\mathrm{b}}$ The information in the description column is taken from the Computational Biology and Bioinformatics Group of the Biosciences Division of Oak Ridge National Laboratory (http://compbio.ornl.gov/public/section/)

${ }^{\mathrm{c}}$ The relative expression was described by the fold change value of genes after ethanol addition with respect to $0 \mathrm{~h}$ 
Table 5. Identification of the differentially expressed proteins of $O$. oeni PSU-1 growing in the presence of ethanol

\begin{tabular}{|c|c|c|c|c|c|c|}
\hline $\begin{array}{l}\text { Spot } \\
\text { no }\end{array}$ & $\begin{array}{l}\text { Gene } \\
\text { symbol }\end{array}$ & $\begin{array}{l}\text { Gene } \\
\text { name }\end{array}$ & $\begin{array}{l}\text { Functional category } \\
\text { Protein name (EC number) }\end{array}$ & $\begin{array}{c}\text { Fold } \\
\text { change* }\end{array}$ & $\begin{array}{l}\text { Theoretical } \mathrm{M}_{r} \\
(\mathrm{kDa})\end{array}$ & $\begin{array}{c}\text { Theoretical } \\
\mathrm{p} I\end{array}$ \\
\hline & & & Nucleotide transport and metabolism & & & \\
\hline $1-2$ & OEOE_1786 & pyrG & CTP synthase (UTP-ammonia lyase) (EC 6.3.4.2) & -5.6 & 60.11 & 5.52 \\
\hline 3 & OEOE_0138 & $n r d L$ & Ribonucleotide reduction protein & -5.4 & 18.05 & 5.52 \\
\hline 4 & OEOE_1069 & apt & $\begin{array}{l}\text { Adenine/guanine phosphoribosyltransferase or related PRPP-binding protein } \\
\text { (EC 2.4.2.7) }\end{array}$ & -3.6 & 19.25 & 5.7 \\
\hline 5 & OEOE_1124 & hpt & Hypoxanthine/guanine phosphoribosyltransferase (EC 2.4.2.8) & -2.7 & 20.93 & 4.99 \\
\hline 6 & OEOE_0437 & -- & Deoxynucleoside kinase (EC 2.7.1.113) & -2.1 & 24.74 & 5.07 \\
\hline $7-8$ & OEOE_0263 & pyrE & Orotate phosphoribosyltransferase (EC 2.4.2.10) & -3 & 23.13 & 5.67 \\
\hline \multirow[t]{2}{*}{9} & OEOE_1036 & $p d x S$ & $\begin{array}{l}\text { Coenzyme metabolism } \\
\text { Pyridoxine biosynthesis enzyme, SOR/SNZ family }\end{array}$ & -3.1 & 31.44 & 5.58 \\
\hline & & & Translation, ribosomal structure and biogenesis & & & \\
\hline 10 & OEOE_0982 & pros & Prolyl-tRNA synthetase (EC 6.1.1.15) & -5.2 & 64.33 & 5.41 \\
\hline 11 & OEOE_0321 & $g \ln S$ & Glutamyl- and glutaminyl-tRNA synthetase (EC 6.1.1.17 - 6.1.1.24) & -2.7 & 57.05 & 5.94 \\
\hline 12 & OEOE_0440 & $\operatorname{ser} S$ & Seryl-tRNA synthetase (EC 6.1.1.11) & -2.4 & 49.86 & 5.68 \\
\hline 13 & OEOE_1694 & gatA & $\begin{array}{l}\text { Asp-tRNAAsn/Glu-tRNAGln aminotransferase A subunit (EC 6.3.5.6- } \\
6.3 .5 .7 \text { ) }\end{array}$ & -2.4 & 52.5 & 5.31 \\
\hline 14 & OEOE_0806 & def & $\mathrm{N}$-formylmethionyl-tRNA deformylase (EC 3.5.1.88) & -2.3 & 21.08 & 5.27 \\
\hline 15 & OEOE_1699 & map & Methionine aminopeptidase (EC 3.4.11.18) & -2.2 & 29.95 & 5.08 \\
\hline 16 & OEOE_1248 & eutG & $\begin{array}{l}\quad \text { Energy production and conversion } \\
\text { Iron-binding alcohol dehydrogenase / aldehyde dehydrogenase family domain } \\
\text { (EC1.1.1.1) }\end{array}$ & -3.8 & 99.1 & 6.04 \\
\hline 17 & OEOE_0635 & $\operatorname{glm} S$ & $\begin{array}{l}\text { Cell envelope biogenesis } \\
\text { Glucosamine 6-phosphate synthetase, amidotransferase and phosphosugar } \\
\text { isomerase domains (EC 2.6.1.16) }\end{array}$ & -3.7 & 66.17 & 5.28 \\
\hline 18 & OEOE_0565 & galU & UDP-glucose pyrophosphorylase (EC 2.7.7.9) & -2.9 & 32.56 & 5.37 \\
\hline 19 & OEOE_1269 & murC & UDP-N-acetylmuramate-alanine ligase (EC 6.3.2.8) & -2.7 & 48.13 & 6.03 \\
\hline 20 & OEOE_1147 & murD & UDP-N-acetylmuramoylalanine-D-glutamate ligase (EC 6.3.2.9) & -2.5 & 48.65 & 6.16 \\
\hline \multirow[t]{2}{*}{21} & OEOE_1447 & $r m l B$ & dTDP-D-glucose 4,6-dehydratase (EC 4.2.1.46) & -2.1 & 37.46 & 5.8 \\
\hline & & & sttranslational modification, protein turnover, chaperones & & & \\
\hline 22 & OEOE_1114 & sufC & Fe-S-cluster assembly ABC-type transport system, ATPase component & -2 & 28.22 & 5.71 \\
\hline 23 & OEOE_0514 & $\operatorname{clp} C$ & $\begin{array}{l}\text { ATP-binding subunit of Clp protease and DnaK/ DnaJ chaperones (subunit of } \\
\text { DnaK/J) }\end{array}$ & -3.2 & 91.48 & 5.86 \\
\hline 24 & OEOE_0640 & $\operatorname{clp} E$ & $\begin{array}{l}\text { ATP-binding subunit of Clp protease and DnaK/ DnaJ chaperones (subunit } \\
\text { clpE) }\end{array}$ & -2.5 & 81.29 & 5.37 \\
\hline \multirow[t]{2}{*}{25} & OEOE_1309 & dnaK & Molecular chaperone & -2.9 & 66.2 & 4.89 \\
\hline & & & Carbohydrate metabolism & & & \\
\hline $26-27$ & OEOE_0135 & $z w f$ & Glucose-6-phosphate 1-dehydrogenase (EC 1.1.1.49) & -2.9 & 55.67 & 6.44 \\
\hline \multirow[t]{2}{*}{28} & OEOE_1523 & gnd & 6-phosphogluconate dehydrogenase (EC 1.1.1.44) & -2.1 & 32.86 & 4.83 \\
\hline & & & Amino acid transport and metabolism & & & \\
\hline \multirow[t]{2}{*}{29} & OEOE_0845 & appF & ABC-type oligopeptide transport system, ATPase component & -2.7 & 34.49 & 5.74 \\
\hline & & & Signal transduction mechanisms & & & \\
\hline \multirow[t]{2}{*}{30} & OEOE_0807 & typA & Stress response membrane GTPase & -3.1 & 68.22 & 5.24 \\
\hline & & & General function prediction only & & & \\
\hline 31 & OEOE_1270 & $\operatorname{arcl}$ & EMAP domain & -2.3 & 22.47 & 6.1 \\
\hline 32 & OEOE_0070 & aral & Aldo/keto reductase related enzyme & -2.1 & 31.68 & 5.6 \\
\hline 33 & OEOE_1072 & $o b g$ & Predicted GTPase & -3 & 48.2 & 5.47 \\
\hline
\end{tabular}



34 OEOE_0531

${ }^{\S}$ Several spot numbers for the same protein entry indicate that the protein was identified in several spots. *Fold-change between ethanol-treated and control gels for each spot at $\mathrm{T}=5 \mathrm{~h}$. 

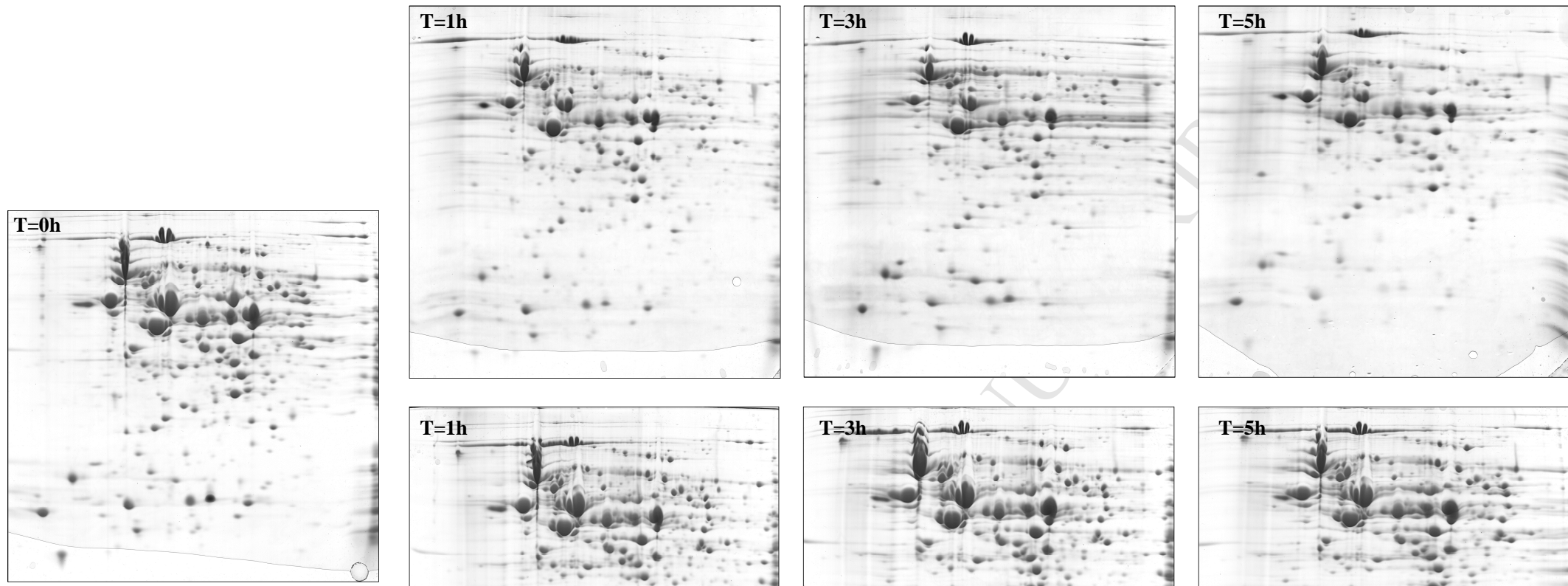

Ethanol addition
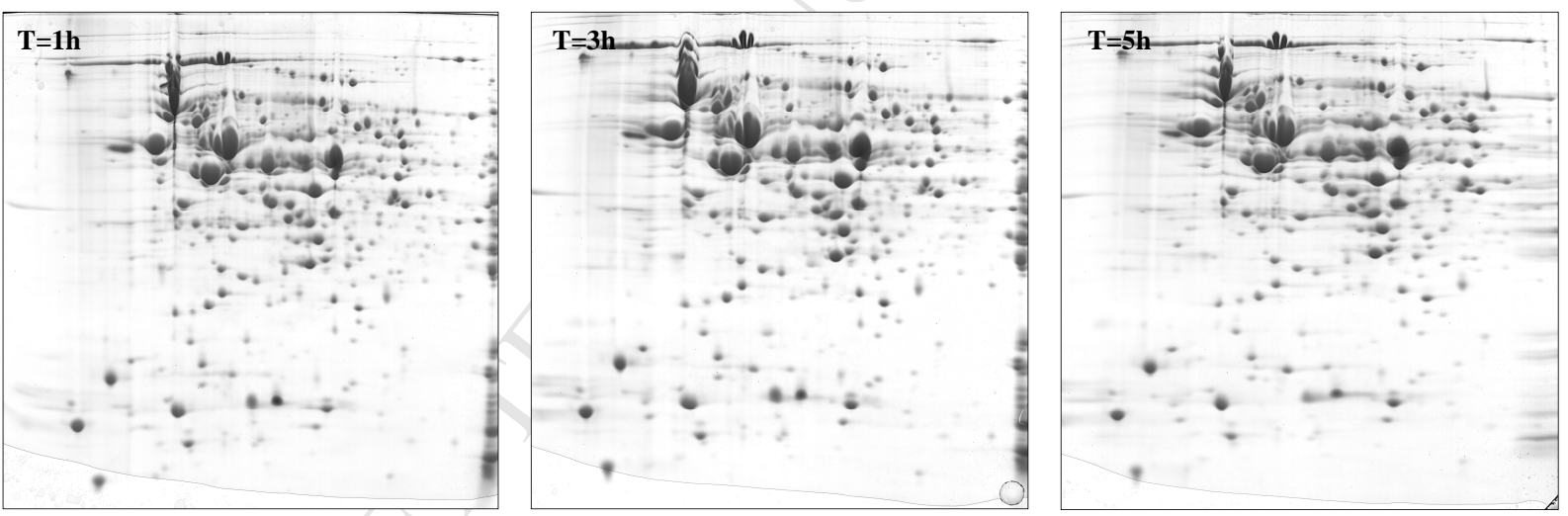

Water addition

Figure S1. Pictures of 2D protein gel of the different conditions assayed: $\mathrm{T}=0 \mathrm{~h}, \mathrm{~T}=1,3$ and $5 \mathrm{~h}$ after ethanol addition (upper side) and after water addition (lower side) 


\section{Highlights}

- Transcriptomic data reveal the inhibition of transport and cell envelope biosynthesis.

- Proteomic results show a decrease in protein biosynthesis and stability.

- Global analysis confirms that the cell membrane is the main target of ethanol damage. 